DOI https://doi.org/10.30525/978-9934-588-45-7.15

\title{
DAPHNIA AND CERIODAPHNIA (CLADOCERA: ANOMOPODA) IN THE CONDITIONS OF THE FLAT HYDROECOSYSTEMS OF WESTERN UKRAINE
}

\section{Ivanets $\mathbf{O}$. R.}

\section{INTRODUCTION}

The problem of biodiversity conservation of zooplanktocenoses, which are key in hydroecosystems, is one of the most pressing. Populations of species of the genera Daphnia and Ceriodaphnia play an important role in trophodynamics, secondary production, and self-purification of reservoirs.

In order to ensure the proper effectiveness of integrated hydroecological monitoring, in accordance with the EU Water Framework Directive (Directive 2000/60 / EC), regional fauna needs special attention. At present, they have not been sufficiently studied.

Our attention was paid to the peculiarities of the taxonomic structure, morphological parameters and ecological characterization of the background species of the genera Daphnia and Ceriodaphnia of the flat hydroecosystems of western Ukraine.

This paper analyzes the results of ecological-faunistic studies of Cladocera.The material (1 883 samples) was selected during 1995-2019 commonly used in hydrobiology methods ${ }^{1}$.

About 970 individuals of the genera Daphnia and Ceriodaphnia were studied. For species identification used , $^{2,4,5,6}$.

Cladocera fauna, structure of cladocerocenoses and their phytophilous complexes, historical aspects of the study of this taxon in western Ukraine have been presented in previous papers ${ }^{7,8,9,10,11,12,13,14,15,16}$.

1 Wetzel R.G., Likens G.E. Limnological analyses. W.B. Saunders Company. Philadelphia - London - Toronto, 1979. 357 p.

2 Іванець О.Р. Систематика та фауністика гіллястовусих раків (Cladocera). Львів : ЛНУ ім. І. Франка, 2019. 384 с.

${ }^{3}$ Błędzki L.A., Rybak J.I. Freshwater Crustacean Zooplankton of Europe: Cladocera \& Copepoda (Calanoida, Cyclopoida). Key to species identification, with notes on ecology, distribution, methods and introduction to data analysis. Switzerland: Springer International Publishing Switzerland. 2016. 918 p.

${ }^{4}$ Dumont H.J., Negrea S.V. Introduction to the class Branchiopoda. Guides to the Identification of the Microinvertebrates of the Continental Waters of the World. Leiden : Backhuys Publishers, 2002. 398 p.

5 Flössner D. Die Haplopoda und Cladocera (ohne Bosminidae) Mitteleuropas. Leiden : Backhuys Publishers, 2000. 428 s.

${ }^{6}$ Hudec I. Fauna Slovenska III. Anomopoda, Ctenopoda, Haplopoda, Onychopoda (Crustacea: Branchiopoda). Bratislava : Veda, 2010. 496 p. 
The morphological and ecological characteristics of Daphnia and Ceriodaphnia were reported by scientific publications and materials of their own observations ${ }^{17,18,19,20,21,22,23,24,25}$.

${ }^{7}$ Іванець О.Р. Фауна гіллястовусих раків (Crustacea, Cladocera) Українського Розточчя. Вісник Львівського університету. Сер. біол. 2013. Вип. 63. С. 110-117.

${ }^{8}$ Іванець О.Р. Таксономічна структура кладоцероценозів Українського Розточчя. Вісник Львівського університету. Сер. біол. 2014. Вип. 64. С. 260-269.

9 Іванець O.P. Фітофільні зоопланктоценози водойм Українського Розточчя. Scientific Journal “ScienceRise”. Біологічні науки. 2014. № 3/1 (3). С. 27-31.

10 Іванець O.P. Таксономічна структура кладоцероценозів Галичини та прилеглих теренів за матеріалами досліджень професора Бенедикта Дибовського. Екологічні науки. 2018. № 4 (23). С. 96-100.

${ }_{11}$ Іванець О.P. Гіллястовусі раки Галичини в дослідженнях професора А. Вежейського. Екологічні науки. 2019. № 4 (27). С. 166-170.

${ }_{12}$ Іванець O.P. Гідробіологічні дослідження Бенедикта Дибовського на теренах Галичини. Професор Бенедикт Дибовський - визначний дослідник спільної природної спадщини Польщі, Білорусі та України. Львів : Компанія «Імперіал», 2018. C. 134-147.

13 Іванець О.Р. Гідроекологічні та кладоцерологічні дослідження професора Бенедикта Дибовського в парадигмі євроінтеграційних процесів України. Екологічні науки. 2018. № 3 (22). С. 164-167.

${ }_{14}$ Іванець O.P. Родина Daphniidae (Cladocera) у палітрі гідробіологічної експозиції Бенедикта Дибовського на Галицькій крайовій виставці 1894 року. Екологічні науки. 2019. № 3 (26). С. 93-98.

${ }^{15}$ Ivanets O.R. Zooplankton of the water vegetation in the ponds of west forest-steppe of Ukraine. Visnyk of the Lviv University. Series Biology. 2011. Issue 56. P. 148-156.

${ }^{16}$ Ivanets O.R. The fauna of Rotatoria and microcrustaceans (Cladocera, Copepoda) of the Ukrainian Roztocze and its surroundings. Development of natural sciences in countries of the European Union taking into account the challenges of XXI century : collective monograph. Lublin : Izdevnieciba "Baltija Publishing", 2018. P. 183-196.

${ }^{17}$ Іванець О.P. Гіллястовусі раки (Cladocera: Daphniidae, Chydoridae) Українського Розточчя: порівняльна характеристика. Вісник Харківського національного університету імені В.Н. Каразіна. Серія «Біологія». 2017. Вип. 29. C. $159-166$.

${ }_{18}$ Błędzki L.A., Rybak J.I. Freshwater Crustacean Zooplankton of Europe: Cladocera \& Copepoda (Calanoida, Cyclopoida). Key to species identification, with notes on ecology, distribution, methods and introduction to data analysis. Switzerland : Springer International Publishing Switzerland. 2016. 918 p.

${ }_{19}$ Flössner D. Die Haplopoda und Cladocera (ohne Bosminidae) Mitteleuropas. Leiden : Backhuys Publishers, 2000. 428 s.

${ }^{20}$ Hudec I. Fauna Slovenska III. Anomopoda, Ctenopoda, Haplopoda, Onychopoda (Crustacea: Branchiopoda). Bratislava : Veda, 2010. 496 p.

${ }^{21}$ Ieromina O., Peijnenburg W.J.G.M., de Snoo G.R., Vijver M.G. Population responses of Daphnia magna, Chydorus sphaericus and Asellus aquaticus in pesticide contaminated ditches around bulb fields. Environmental Pollution. 2014. № 192. P. 196-203.

${ }^{22}$ Ivanets O.R. Zooplankton of the water vegetation in the ponds of west forest-steppe of Ukraine. Visnyk of the Lviv University. Series Biology. 2011. Issue 56. P. 148-156.

${ }^{23}$ Kovalchuk A.A., Ivanets O.R. The impact of damming and water poundage on the formation and structure of zooplanktocoenoses in the conditions of rivers in the Ukrainian Roztocze (the "outer" or "chunk" Carpathians). I Kovalchuk A.A. (ed.) Issues and challenges of small hydropower development in the Carpathians region (hydrology, hydrochemistry, and hydrobiology of watercourses) : monograph. Uzhgorod - L'vivKyiv : Biological Faculty of L'viv National University \& Hydroecological society "Uzh", 2016. P. 138-151. 


\section{Ecomorphology of Daphnia (Cladocera: Anomopoda) of the flat hydroecosystems of Western Ukraine}

In the conditions of the flat hydroecosystems of western Ukraine, the Daphnia genus is represented by six species, three groups of species and two subgenera. In particular, the Daphnia subgenera includes a group of Daphnia (D.) pulex species represented by only one species of Daphnia $(D$. pulex Leydig, 1860 and a group species of Daphnia (D.) longispina represented by three species (Daphnia (D.) longispina (O.F. Müller, 1776); Daphnia (D.) hyalina Leydig, 1860; Daphnia (D.) cucullata Sars, 1862).

The subgenus Ctenodaphnia includes the species Daphnia (C.) magna Straus, 1820 and the species group Daphnia (Ctenodaphnia) similis, represented by the species Daphnia (Ctenodaphnia) carinata King, 1853.

The length of the female $D$. (D.) pulex is $1.39-4.2 \mathrm{~mm}$. The color varies from colorless to yellowish-red. Carapace with noticeable reticulation, oval, without lateral keels, with more or less long apical spine. The back of carapace and the apical spine are covered with spines. The head is low, often with a bulge over the eye, and has a short lateral keel. A compound eye lies close to the anterior margin of the head. Rostrum elongated, acute. Antennule short, not reaching end of rostrum.

Upper lip with densely pubescent distal part. The first abdominal processes is much longer than the others, covered with liquid hairs, the other three are rudimentary, densely pubescent. The postabdomen is elongated and has a slightly convex upper margin, armed with 12-18 denticles, which decrease in the proximal direction. The surface of the postadomen is covered with tufts of very small bristles. Along the concave edge of the abdominal claw is a basal comb of 12-14 thin setae, in the middle - a large comb of 69 denticles, in the distal part very small setae.

The length of the male $D$. (D.) pulex is $0.87-1.6 \mathrm{~mm}$. Unlike the female, the male has almost diamond-shaped carapace, with a straight dorsal margin and a protruding rounded anterior-upper angle, pubescent with long hairs. The upper part of the head protrudes forward. Rostrum is very short, blunt. The first antennas consist of a long, slightly curved base. At their end are aesthetics and flagella. The flagella consists of two joints, the boundary between which is unclear. It is slightly curved, covered with very small bristles in the distal part. A single abdominal processes, covered with rows of small hairs. Somewhat convex in the distal part of the upper edge of the postdomen, as in females, armed with teeth. The vas deferens open between the claws.

${ }^{24}$ Sharma P. Morphological and Molecular Identification of Three Ceriodaphnia Species (Cladocera: Daphniidae) from Australia. Advances in Zoology. Vol. 2014. Article ID 258134, http://dx.doi.org/10.1155/2014/258134. P. 1-14.

${ }_{25}$ Gama-Flores J.L., Castellanos-Paez M.E., Sarma, S. Nandini S.S.S. Life table demography of Ceriodaphnia dubia (Cladocera) exposed to copper at different levels and periods. J. Environ. Biol. 2007. № 28 (3). P. 691-696. 
Species $D$. (D.) pulex eurytopic, $\beta$-mesosaprob. Mainly polycyclic, in pelagial - monocyclic, with two-sex reproduction in the autumn. Number of parthenogenetic eggs up to 67.

Variable are the size of the body and apical spine, the shape of the head and rostrum, the number of teeth on the claws. In the lowland ecosystems of western Ukraine, it occurs in small ponds of floodplain type. Minimum fertility of 2-4 eggs / 9 . Maximum fertility up to $38 \mathrm{eggs} /$ + . Sizes of females: $2.79-3.91 \mathrm{~mm}$. The sizes of males are $1.10-2.33 \mathrm{~mm}$.

Carapace of $D$. (D.) longispina oval. The shape of the head varies: the lower edge is straight or concave, the front edge is straight or with a bulge over the eye, the upper edge is rounded or elongated.

The dorsal head keel is always well developed. The lateral keel, which begins above the eye, bends around the base of the rear antennas to form a blunt angle. There is an abdominal keel that extends from the end of the rostrum to the apex of the head, or is interrupted at the leading edge of the eye. Rostrum is very acute. Eye sizes vary. The pigment spot is developed or is absent. Antennule are short, not reaching end of rostrum. Abdominal processes are well developed. The upper two are long, the lower ones are more or less rudimentary. The postdomen is elongated. Its almost straight upper edge is armed with 9-20 teeth. Abdominal claws are long, thin, covered with small bristles.

The carapace of $D$. (D.) longispina males are narrower than those of females, with a straight dorsal margin. The anterior part of the abdominal margin is slightly elongated and pubescent. Rostrum short, rounded. Antennule with long, slightly curved base, which at the end carries short flagella and sensitive bristles. Postabdomen is less armed than females.

The species $D$. (D.) longispina occurs in reservoirs of different types. Prefers slightly acidic and slightly alkaline. It happens massively in fish farms and reservoirs. Eurythermic, occurs if there is significant contamination. Cyclicality varies - in the literal is a "summer" monocyclic form. Ends the cycle in October-November. Pelagic forms have one (autumn) or two (late spring and autumn) periods of two-sex reproduction. In shallow ponds - polycyclic.

The species is characterized by considerable variability. Seasonal and local variability is characteristic of eye size, head shape and rostrum.

In the conditions of flat ecosystems of western Ukraine belongs to eurytopic species. Occurs both in the literal and pelagic zones of reservoirs. It happens in fish ponds.

Maximum fertility (up to 30 eggs) was observed in the spring. The minimum fertility is $2-3$ eggs. Preferably, the fecundity of 11-18 eggs / 9 . Females size: $1.02-2.73 \mathrm{~mm}$. Male dimensions: $1.39-1.78 \mathrm{~mm}$.

The carapace of the female $D$. (D.) hyalina is broadly oval. Its maximum height is about $70 \%$ of its length. Carapace is thin and transparent, flattened on the sides. The ventral margin is more convex than the dorsal. The length 
of the spines of the dorsal margin is approximately equal to the distance between them. The apical spine is long and its length is about $1 / 4$ to $1 / 2$ the length of the carapace.

The head is wide and low enough. Its length is $25-30 \%$ of the length of the carapace. In the side, in typical shapes, the head has a triangular shape. Its leading edge is evenly curved.

The compound eye is small. Nauplial eye is relatively large. The antennule are reduced. The postdomen is rather narrow. The ephippium resembles the form of the ephippium $D$. longispina, but has slightly smaller spines on the thickened dorsal margin.

The greatest width of the carapace of the male $D$. (D.) hyalina is behind the central part of the carapace. On the ventral side carapace in the central part is slightly concave. In the middle, the edge of the head is evenly and slightly rounded. The ventral margin forms a distinct angle with the dorsal margin. The antennule are similar to the D. longispina antennule, but are slightly thinner. The flagellum is almost nine times longer than the exopodite. Postobdomen narrower than females. Its dorsal margin is slightly concave with 7-9 anal teeth.

$D$. (D.) hyalina euplankton species. Occurs in oligo- and mesotrophic waters. Oligo- and betamezosaprobes. Oligothermal species. The temperature optimum is from 5 to $15^{\circ} \mathrm{C}$.

Typical of the species is a decrease in fertility in summer. Typically, at the time of the first maximum density of 4-12 to 1-7 eggs / 9 . Population density is subject to only minor seasonal variations and is quite high during the growing season.

$D$. (D.) hyalina is characterized by variability. Cyclomorphic changes are observed. Mostly monocyclic, sexual reproduction is observed in September.

In the conditions of the flat hydroecosystems of western Ukraine, the species occurs in pelagic reservoirs. The species is noted, in particular, in fish farms, reservoirs. Characterized by the variability of the apical spine. Fertility of 6-12 eggs / 9 . Female sizes from 0.45 to $1.87 \mathrm{~mm}$. The dimensions of the male are $0.63-1.31 \mathrm{~mm}$.

The carapace of the female $D$. (D.) cucullata transparent, colorless. The length of the female is $0.79-3.1 \mathrm{~mm}$. The body is strongly compressed from the sides. The carapace are elongated, oval, without lateral keels. The apical spine is long, slightly pointed upwards. The shape of the head during the year changes from rounded, low to heavily elongated with a high helmet. The top of the helmet is pointing straight up or slightly forward. Rostrum short, rounded at the end. There is a poorly developed lateral head keel. The eye is small, the pigment spot is absent. The antennule are very short. Their base is hidden by rostrum. The second antennas are long. The ends of the second antennas reach the base of the apical spine.

The two upper abdominal processes are well developed, which have partly grown together. The rest of the abdominal processe are rudimentary. 
Postabdomen is small, short. Its upper edge is slightly convex, armed with 6-9 small teeth. Claws are covered with small bristles.

The length of the male $D$. (D.) cucullata is $0.68-1.54 \mathrm{~mm}$. Unlike females, the dorsal margin of the carapace is almost straight. Head rounded or slightly elongated, pointed. Rostrum stupid. Abdominal processes in the form of two short finger-shaped appendages.

Species $D$. (D.) cucullata resident of pelagic lakes and reservoirs, slowmoving rivers, ponds. Avoids acidic and salty water. Monocyclic, the cycle ends at the end of October.

Typical cyclomorphosis. Local variability manifests itself as a major factor in variations in body size. In small forms the head is relatively lower than in large ones.

The species occurs mainly in the pelagic, but is also noted in the literal zone of reservoirs. It is noted in the reservoirs of abandoned fields, in reservoirs on the roadside, reclamation canals, fish farms. Occurs from midApril at a water temperature of about $12^{\circ} \mathrm{C}$. Fertility of 8-14 eggs / 9 . Size of females: $0.79-3.18 \mathrm{~mm}$. Male sizes: $0.68-1.54 \mathrm{~mm}$.

The colour of the female $D$. (C.) magna is grayish-yellow or reddish. The length of the female is $2.1-6.1 \mathrm{~mm}$. The carapace are oval, broad, with welldeveloped dorsal and lateral keels and a short apical spine. At the base of the apical spine, the lower edge of the carapace forms a characteristic bulge. The dorsal keel, the lower edge of the carapace and apical spine are armed with spikes. Head low, with four keels - dorsal, lateral and two short intermediate.

Rostrum elongated, rounded, sometimes with spines at the end. The eye lies close to the edge of the head. Antennule, located near the end of the rostrum, consist of a short pyramidal base and aesthetascs. The base and segments of the second antenna are densely covered with small bristles. Abdominal processes are well developed. The upper abdominal processes is very long and covered with sparse short hairs. The rest of the abdominal processes have a considerable number of fine hairs in the form of thick down. Abdominal setae short. Postabdomen strongly elongated, with two characteristic notches at the upper edge - a small proximal and deep distal. Between these recesses an anal opening is opened, surrounded on each side by 6-7 teeth. The digital convexity of the upper edge is armed with 912 teeth. The proximal bulge bears small hairs that extend to the lateral side of the postdabdomen. The claws are large, covered with bristles, longer in the proximal part.

The length of the male $D$. $(C$.) magna $1.9-2.3 \mathrm{~mm}$. The apical spine is very short. The abdominal edge of the carapace in front elongated in the form of an angle and densely pubescent. Head low, with blunt rostrum. The big eye. The antennule have a long, narrowed base inside. On the basis of the antennule there is a two-membered flagellum, covered at the end with small bristles, aesthetascs, sensitive bristles and a small sensitive projection. 
Only the lower abdominal processes are developed. The distal part of the postabdomen is elongated in the form of a nipple and armed with teeth. The edges of the anus are convex, surrounded by 10-12 teeth on each side.

Species D. (C.) magna inhabits in temporary ponds, ponds, small freshwater. Species $D$. (C.) magna thermophilic and polycyclic. Fertility up to 100 eggs / 9 .

In the conditions of lowland ecosystems of western Ukraine $D$. $(C$.) magna occurs in small floodplain reservoirs for a rivers, in small reservoirs on pastures in ditches along roads, along reclamation canals. In reservoirs within cities and villages.

Mass development is observed in temporary reservoirs, in fish farms. It happens massively in well-warmed coastal areas. In plankton appears in late March or early April. The maximum fertility observed was up to 84 eggs / o, the minimum was 3-7 eggs / 9 . Preferably, the fertility rate is 25-34 eggs / 9 . Size of females: from 2.19 to $6.2 \mathrm{~mm}$. Male sizes: $1.61-2.3 \mathrm{~mm}$.

The carapace of $D$. $(C$.) carinata females are broadly oval, with a long apical spine. The lower part of the carapace and dorsal keel are covered with thorns. Head low, broad, evenly rounded, with dorsal and lateral keels.

The lateral keel at the base of the second antenna forms a pointed projection. Rostrum elongated and acute. The eye is small. The antennule are short and do not reach the end of the rostrum. The distal end of the base of the second antennas is armed with a number of bristles. Each segment of the exopodite and endopodite of second antennas is armed with a single thorn. Well developed abdominal processes covered with hairs. Abdominal setae are short.

Postabdomen long, slightly constricted distally, with a slightly convex or almost straight upper margin. Its distal part has about 12 teeth, proximal is armed with small spines. The small spines also cover the lateral surface of the proximal portion of the postbdomen. Postabdominal claws are massive with two combs. The upper one consists of 12-13 lower ones - 13-19 teeth. In the distal part of the concave edge, there are small bristles. The anal opening opens in the distal part of the postdomen. The ephippium is fusiform and contains two eggs, which are inclined to the longitudinal axis of the body.

Unlike the female, the carapace of the male $D$. (C.) carinata is elongated, with almost straight edges and a long apical spine. Anterior angle slightly raised, rounded, densely pubescent with long hairs. Head wide, low. Rostrum dull, short. Antennule have an elongated, slightly extended base in the distal part, covered with small spines. At the end of the base are nine aesthetascs, a sensitive bristle and a long two-membered flagella on the distal part of which are short bristles. Of the abdominal processes developed only two - the upper triangular and the middle - semicircular. The upper edge of the postobdomen forms two more or less pronounced bulges. 
Number of anal teeth 6-9. The arms of the claws are the same as those of females, but with fewer teeth in the basal combs.

Species $D$. (C.) carinata is a resident of small temporary, sometimes contaminated reservoirs. Occurs in ponds, reservoirs, river bays. The maximum population development is observed in the summer. Males and ephipyseal females mostly occur in July. Specis is quite variable. First of all, the keel and carapace shapes are variable.

In the conditions of flat ecosystems, western Ukraine often occurs in small and temporary water bodies. Found in fisheries and recreational ponds. It is characterized by sufficient euritopicity. Fertility of 7-18 eggs / 9 . The sizes of females are $2.12-3.42 \mathrm{~mm}$. The sizes of males $-1.42-2.18 \mathrm{~mm}$.

During the study of Daphnia considerable attention was paid to the peculiarities of the structure of their rostrum, which is an important systematic feature. Features of the structure of rostrum were considered only in parthenogenetic females.

Rostrum is a well-developed beak-shaped head growth of Daphnia. According to the structure of rostrum, Daphnia is divided into two morphological types and four subtypes.

The first type is represented by Daphnia, characterized by acute rostrum (D. (D.) longispina, D. (D.) pulex, D. (D.) hyalina, D. (C.) carinata). This type is divided into two morphological subtypes: Daphnia with moderately acute rostrum $(D$. (D.) pulex, D. (D.) hyalina, D. (C.) carinata) and Daphnia with highly acute rostrum $(D$. $(D$.$) longispina )$.

The second morphological type is Daphnia, characterized by rounded rostrum $(D$. (C.) magna, D. (D.) cucullata). This type is also represented by two morphological subtypes: Daphnia, on the rostrum of which there are sharp spikes $(D$. (C.) magna), and Daphnia, whose rostrum has a smooth surface, without spikes $(D .(D$.$) cucullata )$.

When comparing Daphnia species, which in many cases are difficult to distinguish due to the variability of features, it is important to pay particular attention to the peculiarities of their rostrum structure.

Studies have shown that some daphnias, in particular $D$. (D.) longispina, have a violation of the structure of the compound eye. It is shown that in some daphnia ommatidia they do not settle compactly, but are partially destroyed and move away from each other. Daphnia with such organs of vision occurred, first of all, in reservoirs that formed in the ditches along the roads.

Some individuals from the same biotopes have abnormalities in the development of abdominal processes that close the brood chamber where eggs and embryos of parthenogenetic females develop. Such abdominal processes are normally quite long. In some daphnias, studies have shown that they are very short and cannot effectively protect eggs and embryos from dropping out of the brood chamber of females. 


\section{Ecomorphology of Ceriodaphnia (Cladocera: Anomopoda) of the flat hydroecosystems of Western Ukraine}

Six taxa of the genus Ceriodaphnia have been registered in the region of the flat hydroecosystems of Western Ukraine: Ceriodaphnia quadrangula (O.F. Müller, 1785), Ceriodaphnia reticulata (Jurine, 1820), Ceriodaphnia megops Sars, 1861, Ceriodaphnia laticaudata P.E. Müller, 1867, Ceriodaphnia pulchella 1862, Ceriodaphnia dubia Richard, 1894.

C. quadrangula is characterized by a carapace with a distinct reticulation. The ventral edge of the carapace is semicircular and the dorsal is slightly curved. Upper back angle of the carapace looks like thorny outgrowth. The lateral keel of $C$. quadrangula is characterized by polymorphism of the features. It may have a tapered projection or be smooth. The distal portion of the postbdomen is much lower than the proximal one. The number of anal teeth is in the range from 6 to 9. The postdomenal claws on the concave edge bear rather small bristles. The length of $C$. quadrangula females varies from 0.57 to $0.91 \mathrm{~mm}$. Definitive sizes of males are generally smaller, from the sizes of females and range from 0.47 to $0.69 \mathrm{~mm}$. C. quadrangula is widespread in the literal zone of reservoirs, often registered in the pelagia. It is noted in the ponds, coastal biotopes of slow-flowing streams. The life cycle is characterized by monocyclicity. In the summer, four to 9 eggs are present in the brood chambers of C. quadrangula females.

C. reticulata carapace form a well-developed posterior angle in the form of a thorny pointed projection. The head of $C$. reticulata, in comparison with other representatives of this genus, is somewhat larger in size, the lateral keel also well developed. The postabdomen of $C$. reticulata is distally gradually narrowing. The number of anal teeth varies from 7 to 12 , with the average being longer than the extreme teeth. The arms of the postbdomen claws are different from C. quadrangula, because, in addition to a number of dense small bristles, a basal comb is located here. The number of teeth in this structure is quite variable and varies from 2 to 7 . The size of C. reticulata females varies from 0.72 to $1.51 \mathrm{~mm}$. Abdominal growth in males of $C$. reticulata is absent. The sizes of males vary from 0.49 to $0.81 \mathrm{~mm}$. C. reticulata species is quite widespread and is characterized by evrytopia. It occurs in floodplains, ponds, ponds along roads, temporary reservoirs that do not dry out for a long time. In large reservoirs there is a monocycle with the appearance of males in the autumn period of the growing season. In small astatic reservoirs the species is dicyclic. In some cases, there is a polycycle.

Females of $C$. megalops have a greenish-red carapace with structural elements in the form of strips in the medial part. The anterior posterior angle of the carapace is pointed. The low or straight head lateral keel is marked by polymorphism and may have a small angle. C. megalops has a rather characteristic postabdomen, which in the distal part of the upper edge forms the angle at which the small denticles lie. The number of anal teeth that are 
distally enlarged varies slightly (from 7 to 9). The sizes of females vary from 1.11 to $1.52 \mathrm{~mm}$. The sizes of males range from 0.73 to $0.85 \mathrm{~mm}$. $C$. megalops occurs primarily in the coastal area of the ponds, in the floodplains a rivers, among the thickets of aquatic vegetation. There are between 13 and 20 eggs in a female brood chamber, the life cycle is characterized by a monocycle.

The carapace of the female $C$. laticaudata is characterized by a yellowbrown pigmentation, in some cases it acquires a reddish tinge. Carapace on the upper back edge form a small spike. The back of lateral keel of head is somewhat pointed. The greatest height of the postabdomen is observed in its middle part due to the bulge formation, the abdominal processes is long and pointed. The number of anal teeth varies slightly, usually nine or ten. The middle ones are larger than the extreme ones. On the postbdomen claws are thin bristles. The length of the females varies from 0.79 to $1.15 \mathrm{~mm}$. The sizes of males vary from 0.68 to $0.75 \mathrm{~mm}$. The species is characteristic, first of all, for astatic reservoirs. Occurs also in the literal zone of ponds, among the thickets of aquatic plants, in the floodplains a rivers. The life cycle is characterized by monocycle, in temporary reservoirs sometimes observed dicyclicity. Males and females with ephippiums occur in September and October.

Carapace C. pulchella have a posterior angle in the shape of a fairly long spike. The lateral keel is polymorphic, may have straight edges or a studded projection. The postabdomen forms an indentation before the anus. The arms of the upper edge of the postdomen are quite characteristic: in addition to 35 bristles collected in a bundle, there are 8-10 teeth, distally increasing in size. Postbdomen claws carry bristles. The sizes of females vary from 0.68 to $0.95 \mathrm{~mm}$. The sizes of males of $C$. pulchella vary from 0.49 to $0.65 \mathrm{~mm}$. C. pulchella occurs in the coastal zone of river, where the flow is slower, in ponds, astatic reservoirs that do not dry for a long time. In pelagic zone begins to occur, usually in the second or third decade of May. The life cycle is characterized by a monocycle, in dystatic reservoirs sometimes observed dicyclic. Females with ephippium and males are observed in OctoberNovember.

The carapace of $C$. dubia females on the dorsal margin is slightly convex and slightly pigmented, with a gray tinge, has a well-marked reticulation. The posterior angle of the carapace is long enough, shaped like a thorn and pointing upwards. The ventral edge of the head bears small spines and is slightly convex. C. dubia is characterized by two abdominal processes of different lengths: upper - longer and lower - shorter. The postabdomen is proximal higher than in the distal, rounded region. Its upper edge is slightly concave in the middle part. The number of anal teeth is quite variable (usually 7 to 12). C. dubia occurs in reservoirs with slow water exchange, in ponds, astatic hydroecosystems, floodplains a rivers, among the thickets of aquatic vegetation. 
The males of $C$. dubia differ from the females by the straight upper edge of the carapace. On their carapace develops a directed back and up projection in the form of a thorn. On the first pair of legs develops a long bristle that goes beyond the middle of the carapace. Postabdomen in structure is similar to the postobdomen of the female.

\section{CONCLUSIONS}

Six species of Daphnia have been found in the reservoirs of flat hydroecosystems of western Ukraine: $D$. $(D$.) pulex, $D$. (D.) longispina, $D$. $(D)$. hyalina, D. (D.) cucullata, D. (C.) magna, D. (C.) carinata King, 1853. 15

The registered species belong to two subgenera (Daphnia and Ctenodaphnia) and three groups of species (D. (D.) pulex, D. (D.) longispina, D. (C.) similis).

Four morphological subtypes and two types of Daphnia are distinguished by the structure of rostrum in the flat hydroecosystems of western Ukraine conditions. The first type is characterized by a sharp rostrum. It includes a subtype with moderately acute rostrum $(D$. (D.) pulex, D. (D) hyalina, $D$. $(C$.) carinata) and a subtype with highly acute rostrum (D. (D.) longispina). The second morphological type of Daphnia is characterized by rounded rostrum. It includes a subtype with acute spines on rostrum $(D .(C)$. magna) and a subtype characterized by rostrum without spines $(D$. $(D)$. cucullata).

Some daphnias have abnormalities in the visual organs and abdominal processes that close the entrance to the brood chamber.

The morphological and ecological studies of Cladocera of the genus Daphnia need further attention. It is particularly important to identify the causes that lead to impaired visual organs and abdominal processes. In particular, it is necessary to use genetic methods of study, the results of which would be confirmed by statistically significant morphological characteristics. Clarification of the status of populations of species of the genus Daphnia will help them clearly differentiate, compare with the samples of adjacent regions, and determine the status of other forms. Such works are important, in particular, for Cladocera biogeographic studies.

The genus Ceriodaphnia is represented by 6 taxa: C. quadrangula, C. reticulata, C. megops, C. laticaudata, C. pulchella, C. dubia. They are characterized by polymorphism of the main lateral keel, the posterior angle of the carapace, its reticulation and the arms of the postdomen. Plasticity, variability of life cycle forms, significant biotopic representation, indicate significant adaptive capacity of Ceriodaphnia, the formation of intraspecific taxa in this group. The peculiarities of adaptive population strategies of Ceriodaphnia, due to the variability of generative cycles and morphological characteristics, require further biocenotic studies using the latest methods of ecology and genetics. 


\section{SUMMARY}

The morphological and ecological characteristics of the genera Daphnia and Ceriodaphnia of the flat hydroecosystems of western Ukraine were investigated. Six species of Daphnia were identified: $D$. (D.) pulex, D. (D.) longispina, $D$. (D.) hyalina, D. (D.) cucullata, D. (C.) magna, D. (C.) carinata. The registered species belong to two subgenera (Daphnia and Ctenodaphnia) and three groups of species $(D .(D$.$) pulex, D$. (D.) longispina, D. (C.) similis). Clarification of the status of populations of species of the genus Daphnia will help them clearly differentiate, compare with the samples of adjacent regions, and determine the status of other forms. Such works are important, in particular, for Cladocera biogeographic studies.

The genus Ceriodaphnia is represented by 6 taxa: $C$. quadrangula, C. reticulata, C. megops, C. laticaudata, C. pulchella, C. dubia. Plasticity, variability of life cycle forms, significant biotopic representation, indicate significant adaptive capacity of Ceriodaphnia, the formation of intraspecific taxa in this group.

\section{REFERENCES}

1. Іванець О.Р. Фауна гіллястовусих раків (Crustacea, Cladocera) Українського Розточчя. Вісник Львівського університету. Сер. біол. 2013. Вип. 63. С. 110-117.

2. Іванець О.Р. Таксономічна структура кладоцероценозів Українського Розточчя. Вісник Львівського університету. Сер. біол. 2014. Вип. 64. С. 260-269.

3. Іванець О.Р. Фітофільні зоопланктоценози водойм Українського Розточчя. Scientific Journal "ScienceRise”. Біологічні науки. 2014. № 3/1 (3). C. 27-31.

4. Іванець О.Р. Гіллястовусі раки (Cladocera: Daphniidae, Chydoridae) Українського Розточчя: порівняльна характеристика. Вісник Харківського національного університету імені В.Н. Каразіна. Серія «Біологія». 2017. Вип. 29. С. 159-166.

5. Іванець О.P. Гідробіологічні дослідження Бенедикта Дибовського на теренах Галичини. Професор Бенедикт Дибовський визначний дослідник спільної природної спадщини Польщі, Білорусі та України. Львів : Компанія «Імперіал», 2018. С. 134-147.

6. Іванець О.Р. Гідроекологічні та кладоцерологічні дослідження професора Бенедикта Дибовського в парадигмі євроінтеграційних процесів України. Екологічні науки. 2018. № 3 (22). С. 164-167.

7. Іванець О.Р. Таксономічна структура кладоцероценозів Галичини та прилеглих теренів за матеріалами досліджень професора Бенедикта Дибовського. Екологічні науки. 2018. № 4 (23). С. 96-100.

8. Іванець О.Р. Родина Daphniidae (Cladocera) у палітрі гідробіологічної експозиції Бенедикта Дибовського на Галицькій 
крайовій виставці 1894 року. Екологічні науки. 2019. № 3 (26). С. 93-98. DOI https://doi.org/10.32846/2306-9716-2019-3-26-18.

9. Іванець О.Р. Гіллястовусі раки Галичини в дослідженнях професора А. Вежейського. Екологічні науки. 2019. № 4 (27). C. 166-170. DOI https://doi.org/10.32846/2306-9716-2019-4-27-25.

10. Іванець О.Р. Систематика та фауністика гіллястовусих раків (Cladocera). Львів : ЛНУ ім. І. Франка, 2019. 384 с.

11. Błędzki L.A., Rybak J.I. Freshwater Crustacean Zooplankton of Europe: Cladocera \& Copepoda (Calanoida, Cyclopoida). Key to species identification, with notes on ecology, distribution, methods and introduction to data analysis. Switzerland : Springer International Publishing Switzerland. 2016. 918 p.

12. Dumont H.J., Negrea S.V. Introduction to the class Branchiopoda. Guides to the Identification of the Microinvertebrates of the Continental Waters of the World. Leiden : Backhuys Publishers, 2002. 398 p.

13. Flössner D. Die Haplopoda und Cladocera (ohne Bosminidae) Mitteleuropas. Leiden : Backhuys Publishers, 2000. 428 s.

14. Gama-Flores J.L., Castellanos-Paez M.E., Sarma, S. Nandini S.S.S. Life table demography of Ceriodaphnia dubia (Cladocera) exposed to copper at different levels and periods. J. Environ. Biol. 2007. № 28 (3). P. 691-696.

15. Hudec I. Fauna Slovenska III. Anomopoda, Ctenopoda, Haplopoda, Onychopoda (Crustacea: Branchiopoda). Bratislava : Veda, 2010. 496 p.

16. Ieromina O., Peijnenburg W.J.G.M., de Snoo G.R., Vijver M.G. Population responses of Daphnia magna, Chydorus sphaericus and Asellus aquaticus in pesticide contaminated ditches around bulb fields. Environmental Pollution. 2014. № 192. P. 196-203.

17. Ivanets O.R. Zooplankton of the water vegetation in the ponds of west forest-steppe of Ukraine. Visnyk of the Lviv University. Series Biology. 2011. Issue 56. P. 148-156.

18. Ivanets O.R. The fauna of Rotatoria and microcrustaceans (Cladocera, Copepoda) of the Ukrainian Roztocze and its surroundings. Development of natural sciences in countries of the European Union taking into account the challenges of XXI century : collective monograph. Lublin : Izdevnieciba "Baltija Publishing", 2018. P. 183-196.

19. Kovalchuk A.A., Ivanets O.R. The impact of damming and water poundage on the formation and structure of zooplanktocoenoses in the conditions of rivers in the Ukrainian Roztocze (the "outer" or "chunk" Carpathians). I Kovalchuk A.A. (ed.) Issues and challenges of small hydropower development in the Carpathians region (hydrology, hydrochemistry, and hydrobiology of watercourses) : monograph. Uzhgorod - L'viv - Kyiv : Biological Faculty of L'viv National University \& Hydroecological society “Uzh”, 2016. P. 138-151. 
20. Sharma P. Morphological and Molecular Identification of Three Ceriodaphnia Species (Cladocera: Daphniidae) from Australia. Advances in Zoology. Vol. 2014, Article ID 258134, DOI http://dx.doi.org/10.1155/2014/ 258134. P. 1-14.

21. Wetzel R.G., Likens G.E. Limnological analyses. W.B. Saunders Company. Philadelphia - London - Toronto, 1979. 357 p.

\section{Information about author:} Ivanets $\mathbf{O}$. R., Candidate of Biological Sciences, Associate Professor at the Department of Zoology of the Biology Faculty Ivan Franko National University of Lviv 4, Hrushevskoho str., Lviv, 79005, Ukraine 